\title{
Idejna in umetniška identiteta mladinskih zborov med obema vojnama
}

\author{
Darja Koter \\ Univerza v Ljubljani \\ University of Ljubljana
}

Stanko Vurnik (1898-1932), vodilni ideolog slovenske glasbene umetnosti dvajsetih let 20. stoletja, se je kot poznavalec svetovnih in evropskih družbeno-političnih, duhovnih in umetnostnih gibanj kritično odzival na aktualne prelomnice človeštva. V svojih ostrih zapisih o šibki odzivnosti slovenskih kulturnikov in posebno glasbenikov na družbene in posledično umetnostne spremembe po prvi svetovni vojni, je poudarjal, da:

"Problemi nove kulturnosti ne morejo biti nič drugega kakor problemi novega človeka, nove duhovne smeri, kratko: novih svetovno-nazornih osnov. Te osnove so namreč tista osrednja os, ki oblikuje in giblje vse socialno, gospodarsko, politično, kulturno, religiozno in umetnostno življenje vsake dobe $v$ čudovito organičen sistem, katerega vsi sestavni deli enotno odžarevajo vsebino svojih osnov. "

Kot edino pravo pot, ki vodi k »novim« časom in »novi« umetnosti, je zagovarjal temeljno preobrazbo vsesplošne miselnosti, umetnostnih nazorov in glasbenih pojavov, stavil na odprtost v svet in glasbeno izobraževanje v »novem duhu « ter o tem zapisal:

"In vendar mora nov čas pokazati nove ljudi in preobraziti tudi naše glasbeno življenje prav do korenine. Na vseh poljih, na vseh panogah mora vzkliti najprej nova kulturna orientacija, z njo nov umetnostni nazor, našemu času potreben in primeren, potem šele 
bo konec te čudne stagnacije, iz katere ne moremo nikamor dalje. In vendar moramo Slovenci ravno z glasbo iskati svetovnega uveljavljenja, ker nam na drugih poljih ni tako lahko prodreti $v$ svet in koristiti svetovni kulturi ... Zato pa treba vzgojiti nove generacije glasbenikov v novem duhu .... ${ }^{2}$

Vurnik je kot privrženec Guida Adlerja je poznal slogovne novosti, ki so prežemale svet severno in zahodno od slovenskega prostora in se čutil dolžnega, da o tem razsvetli širšo slovensko glasbeno javnost. ${ }^{3}$ Ker se je zavedal ekspresionistične stvarnosti druge dunajske šole, nove glasbene arhitektonike, racionalnosti umetniškega izražanja in ne nazadnje nadnacionalnih pojavov, je širšo javnost nagovarjal k novemu. Čeprav ekspresionizma ni postavljal na piedestal, neobaročne oziroma neoklasicistične slogovne značilnosti pa je v svojem času šele slutil, je bil dovolj osveščen, da je kot predstavnike novosti izpostavljal osebnosti, kot so Busoni, Schönberg, Křenek, Hindemith, Stravinski.... Svojih misli zaradi prezgodnje smrti sicer ni uspel povsem razviti in utemeljiti, vendar je $\mathrm{z}$ opredelitvijo proti romantičnim in impresionističnim slogovnim značilnostim in poudarjanjem potreb po "novem« spodbujal sodobnejša razmišljanja ter tako tlakoval pot aktualnim glasbenim pojavom $\mathrm{v}$ kompoziciji in poustvarjalnih navadah, ki so jih drug za drugim sprejemali in razvijali nekateri najbolj osveščeni slovenski glasbeniki. Pot k sodobnejšim glasbenim tokovom zahodnega sveta je bila za slovenske glasbenike precej strma, večino je ovirala privrženost $\mathrm{k}$ tradicionalnemu in ne nazadnje je bilo zanje $\mathrm{v}$ omenjenem času še vedno malo možnosti izobraževanja na vodilnih evropskih glasbenih ustanovah. Družbene oziroma socialne okoliščine so bile tiste, ki so najbolj omejevale mlade glasbene talente pri uresničevanju njihovih poklicnih željah. Naj spomnimo, da je ljubljanski konservatorij, ustanovljen leta 1919, nudil izobraževanje na nižji in srednji stopnji. Eden temeljnih vzrokov, da ni bilo možnosti visokošolskega študija, je bilo pomanjkanje primerno izobraženih učiteljev z zaključeno visoko stopnjo izobrazbe na ustreznih evropskih ustanovah.

Za razmislek o tem, kaj je oviralo in spodbujalo približevanje slovenske glasbe k razvitejšim sredinam, so med drugimi povedni Vurnikovi zapisi, s katerimi se je odzival na koncertno in operno poustvarjalnost ak-

2 Stanko Vurnik, »Glasbeno življenje v Ljubljani 1. 1930«, Dom in svet 44, 1-2 (1931): 95.

3 Glej Vurnikovo najobsežnejše teoretično delo: Stanko Vurnik, Uvod v glasbo. I. Sistematični del (Ljubljana: Nova založba, 1929). 
tualnega časa, na dosežke posameznih skladateljev in delovanje takrat osrednjih izobraževalnih glasbenih ustanov, ljubljanske Glasbene matice in Konservatorija. Njegova poročila in kritiški zapisi odražajo stanje duha in glasbene prakse. Med velikimi pomanjkljivostmi desetletja po prvi vojni, ki so vplivale na slogovno in repertoarno raven glasbenega delovanja, je izpostavljal, da Ljubljana ni premogla pravega simfoničnega orkestra, da slovenski skladatelji niso bili sposobni napisati orkestralnih del večjega formata, da je bila ljubljanska Opera $\mathrm{z}$ redkimi izjemami vpeta $\mathrm{v}$ tradicionalni program ${ }^{4}$, da so koncertni podij v preveliki meri obvladovali skladatelji romantičnih in impresionističnih nazorov, ki mladih niso spodbujali $\mathrm{k}$ sodobnejšim kompozicijskim prijemom, da se je zbor ljubljanske Glasbene matice kot osrednji slovenski vokalni ansambel na svojih mednarodnih turnejah predstavljal s pretežno slogovno "zastarelim « programom in ne nazadnje je poudarjal zastarelost konservatorija, ki mu je očital preživete in $\mathrm{z}$ Evropo neprimerljive učne programe. ${ }^{5} \mathrm{~V}$ svojem umetnostnem manifestu, objavljenem v Ljubljanskem zvonu leta 1926, je opozoril, »da je naloga umetnostne politike pospeševati mednarodno umetnostno komunikacijo $z$ oddajanjem in sprejemanjem ... « ${ }^{6} \mathrm{~S}$ tem je apeliral na mednarodno uveljavljanje slovenskih skladateljev in poustvarjalcev, ki bi prineslo prepoznavnost slovenske glasbene umetnosti in večji pretok sodobnih slogovnih oziroma kompozicijskih idej.

Pregled slovenske glasbene poustvarjalnosti potrjuje številne Vurnikove ugotovitve, med drugim, da je bil največji repertoarni ter z njim slogovni in kompozicijsko-tehnični napredek na področju poustvarjanja vokalne glasbe, v čemer sta v letih 1927-1930 izstopala dva ansambla, v Ljubljani delujoča Pevski zbor slovenskih učiteljev pod vodstvom Srečka Kumarja in moški Akademski pevski zbor pod vodstvom Franceta Marolta. Oba sta v sezoni 1930 nastopala s pretežno novejšimi deli slovenskih oziroma jugoslovanskih avtorjev, v katerih je najti ekspresionističen izraz, ostrej-

$4 \quad$ Vurnik je nekatere poustvarjalne dosežke ljubljanske Opere pod vodstvom Mirka Poliča ob koncu 20. let, takrat aktualna dela Stravinskega, Šostakoviča, Křeneka in Prokofjeva ter med slovenskimi novitetami sodobnih slogovnih tokov dela Kogoja, Osterca in Bravničarja, prepoznal kot izjemne, hkrati pa ugotovil, da je nadaljnji razvoj Opere upočasnila in zavrla državna politika ter gospodarska kriza začetka 30. let. Prim: Stanko Vurnik, »H krizi naše Opere«, Dom in svet 43, 1-2 (1930): 58-59.

5 Vurnik je svoja opažanja strnil v letnih poročilih in jih objavljal v reviji Dom in svet 39, 1 (1926): 61-64; 40, 1 (1927): 47-50; 41, 6 (1928): 191-92; 42, 1-2 (1929): 62-64; 43, 1-2 (1930): 57-59; 44, 3-4(1931): 190-92.

6 Stanko Vurnik, »Umetnost in družba ter umetnostna politika«, Ljubljanski zvon 46, 4 (1926): 244. 
še melodične napetosti in rahljanje tonalitet, ter se uveljavljala na širši glasbeni sceni na območju takratne Jugoslavije in v nekaterih drugih evropskih slovanskih državah. Prvi je tega leta izvedel uspešno koncertno turnejo po Češkoslovaški, Akademski pa je s skladbami Marija Kogoja in Janka Ravnika nastopal v Beogradu.

Nedvomno so se avantgardni umetnostni pojavi na Slovenskem utrjevali počasi, v manjših, deloma celo v zaprtih umetniških krogih, saj je bila tradicija zelo zakoreninjena, novosti pa podvržene ostri netolerantni kritiki. Med najbolj napredno mislečimi je bila skupina v krogu Kluba mladih (ustanovljen leta 1920) pod vodstvom pesnikov Antona Podbevška in Mirana Jarca ter slikarjev Božidarja Jakca in Riharda Jakopiča, ki je s svojimi kulturnimi manifestacijami, znanimi kot "novomeška pomlad«, tlakovala pot prihajajočim generacijam umetnikov. To je bil čas, ko so se pojavljale vedno nove umetnostne smeri, futurizem, dadaizem, kubizem in konstruktivizem, Srednja Evropa pa se je najbolj ogrela za ekspresionizem. Slovenski mladi umetniki so izražali težnje po drugačnem, nematerialističnem svetu, ter $\mathrm{z}$ ekspresionističnimi in konstruktivističnimi deli stopali po poti nove stvarnosti oziroma novega realizma. ${ }^{8}$ Pomenljivo napredna sta bila gledališka režiserja Ferdo Delak in Bratko Kreft, medtem ko so bili med skladatelji sodobnih glasbenih tokov le tisti, kot pravi Matija Bravničar, "prežeti z željo ustvariti nekaj povsem novega, brez kompromisov, z zavestnim tveganjem in kljubovanjem «. ${ }^{9}$ Prvi med njimi je bil Marij Kogoj kot ekspresionist $z$ dunajskimi vzori Arnolda Schönberga in Franza Schrekerja, ki je leta 1927 dokončal za slovensko zgodovino epohalno opero Črne maske. Njegov vpliv je sooblikoval Matijo Bravničarja, ki je svojo prvo opero s socialno tematiko Pohujšanje $v$ dolini šentflorjanski (dokončana 1930) zasnoval v slogu operne farse. Med najnaprednejšimi pa je bil praški diplomant Slavko Osterc, privrženec ekspresionizma in kasneje neoekspresionizma ter zagovornik Hábovega četrttonskega sistema, ki je kot profesor kompozicije na ljubljanskem konservatoriju od leta 1927 bíl bitko z zastarelim učnim programom in njegovimi zagovorniki. S svojimi sodob-

Stanko Vurnik, »Glasbeno življenje v Ljubljani 1. 1930«, Dom in svet 44, 1-2 (1931): 95 . prazgodovine do danes, Stane Bernik et al. (Ljubljana: Mladinska knjiga, 1998): 26370.

9 Darja Koter, »Matija (Frane) Bravničar - prispevek k biografiji«, Matija Bravničar (1897-1977), Tematska številka Glasbeno-pedagoškega zbornika Akademije za glasbo, zv. 9, ur. Darja Koter (Ljubljana: Akademija za glasbo, 2008), 15. 
nimi umetnostnimi nazori je kot eden prvih skladateljev svojega časa zaznamoval več generacij mladih glasbenikov, ki so komponirali v sodobnem duhu, tudi v atonalnem slogu, ter se skupaj z njim uveljavljali na festivalih sodobne glasbe v okviru mednarodnega združenja SIMC (Société internationale de musique contemporaine). Prvi slovenski avantgardizem je dosegel vrhunec $\mathrm{z}$ revijo Tank (1927), katere pisci so o razvoju nove umetnosti razpravljali tudi v znani umetnostni reviji Der Sturm, ki je leta $1929 \mathrm{v}$ posebni številki objavila dejavnost avantgardnega, t. i. Novega odra Ferda Delaka, komentar h konstruktivistični razstavi slikarja Avgusta Černigoja in h glasbenemu opusu Marija Kogoja, sicer pretirano označenega za predstavnika atonalne glasbe. ${ }^{10}$ Med večje dosežke, ki so bili plod evropskih novih gibanj, smemo šteti tudi nekatere poustvaritve ljubljanske Opere pod vodstvom Mirka Poliča, ki je poleg Kogojevih Črnih mask (1929) izvedla nekaj zares aktualnih del širšega evropskega prostora, kot so bile Zaljubljen v tri oranže (1927) Sergeja Prokofjeva, Oedipus Rex (1928) Igorja Stravinskega in ne nazadnje Ernsta Křeneka Johnny spielt auf (nastala 1927, v Ljubljani 1928). Nujnosti pretoka sodobnejših idej v slovensko ustvarjalnost in poustvarjalnost se je začel zavedati tudi odbor Glasbene matice, ki je, ne brez turbulentnih dogovarjanj, podprl predlog Emila Adamiča o izdajanju sodobne glasbene revije Nova muzika. Njeno idejno usmeritev in vizijo $\mathrm{k}$ »novemu « so v uvodu prve številke leta 1928 predstavili tako urednik Adamič kot umetnostni ideolog Vurnik ter Osterc, ki je na tem mestu zapisal svoj umetniški manifest in ga zaokrožil z motom: »Delajmo in študi-

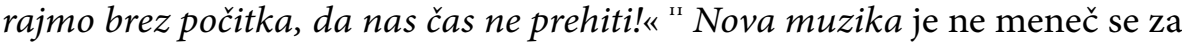
kritike uresničila marsikaj od zastavljenega, spodbujala je dela v slogu aktualnih evropskih gibanj, objavila vrsto novih skladb mlajših in najmlajših slovenskih skladateljev, pa tudi dela hrvaških, srbskih, čeških, poljskih in nekaterih drugih avtorjev, ter vseskozi sledila svojim ciljem - predstavljati sodobnejše kompozicijske prijeme. Med kompozicijsko najradikalnejšimi objavami so bila dela čeških skladateljev (Otakar Ostrčil, Rudolf Karel, Jaroslav Křička, Karel Boleslav Jirák, Alois Hába idr.), med slovenskimi pa Slavka Osterca, Demetrija Žebreta in Srečka Koporca. Žebre je predstavnik praške mojstrske šole Josefa Suka in Aloisa Hábe ter eden ključnih modernistov slovenskega prostora svojega časa, Koporc pa je bil dunajski študent Schönbergovega učenca Egona Lustgartna. Adamič je revijo uspešno distri-

10 Ervin Dolenc, »Avantgarda v umetnosti - konstruktivizem«, Slovenska kronika XX. stoletja (Ljubljana: Nova revija...), 307.

11 Slavko Osterc, "Glavne struje sodobne glasbe in njih eksistenčna upravičenost«, Nova muzika 1, 1 (1928): 1-2. 
buiral v nemške, češke in druge slovanske glasbene kroge, $s$ čimer je uresničeval idejo razširjanja mlade slovenske glasbe. Kljub aktualnosti, pretoku idej in dobri uredniški politiki revija zaradi nasprotovanj tradiciji zavezanih slovenskih krogov ni obstala in je po dveh letih prenehala izhajati. ${ }^{12} S$ tem so bile prekinjene nadvse pomembne ustvarjalne spodbude mladim skladateljem, ki jim je Nova muzika nudila oporo ter omogočala predstavitev v domačih in tujih glasbenih krogih. V naslednjih dveh desetletjih slovenska glasbena scena ni zmogla ustvariti podobno pomembne revije, ki bi zastopala širok spekter sodobne glasbene ustvarjalnosti.

Kljub številnim oviram, ki so v obravnavanem času vplivale na kulturno raven slovenske umetnosti, so $\mathrm{v}$ danih razmerah nastajali posamezni zbori, ki so presegli slovensko povprečje in se močno približali idealom razvitejših evropskih sredin. Odrasle in mladinske zbore je k "novemu« spodbudil že omenjeni Pevski zbor slovenskih učiteljev, ki je imel odlične vzore. To je bil izjemno odmeven, že pred prvo svetovno vojno mednarodno uveljavljen moški zbor Pevske zveze moravskih učiteljev, ki je deloval pod vodstvom Ferdinanda Vacha in se proslavil z odlično pevsko tehniko in izbornim programom. Decembra leta 1907 je nastopil v Ljubljani in Trstu ter vzbudil posnemanja vredno občudovanje. ${ }^{13}$ Njegov nastop je med slovenskimi učitelji in zborovodji odmeval več let in bil ponovno v ospredju leta 1922, ko je isti dirigent $\mathrm{v}$ Ljubljani nastopil z ženskim zborom društva, ki je veljal za edinstvenega. Pisec poročila o tem koncertu Josip Michl, po rodu Čeh, sicer pa vpliven učitelj goriškega učiteljišča, je zapisal, da sta oba zbora epohalna ter da je dirigent Vach rešitelj češke zborovske glasbe, ki je na začetku 2o. stoletja ob sicer velikem vzponu instrumentalne glasbe stagnirala. Ferdinand Vach, prej neznani učitelj petja na učiteljišču, je v okviru zveze učiteljskih društev zbral nekdanje učence in sestavil zbor visoko motiviranih pevcev, s katerimi je ob trdem delu kmalu dosegel odlično pevsko tehniko in zmožnost umetniškega poustvarjanja. Pevci so na vaje prihajali iz različnih krajev, pripravljeni na skupno delo. Zbor je kmalu dosegel zavidljive uspehe in mednarodno priznanje ter postal vzor drugim češkim zborovodjem in zborom. Število zborov je skokovito naraščalo, kvaliteta je bila vse višja. Ob tem Michl poudarja, da so češki skladatelji ob poslušanju obeh Vachovih zborov, njunem ubranem, intonančno čistem in umetniško prepričljivem petju začeli množično ustvarjati nove skladbe ter tako poskrbeli za ponov-

12 Darja Koter, "Glasbena revija Nova muzika - Adamič kot urednik«, Adamičev zbornik (2004): 63-75. 
ni vzpon zborovske literature in njeno kompozicijsko posodobitev. ${ }^{14}$ Uspeh Vachovih zborov je močno odmeval med slovenskimi učitelji, zborovodji in skladatelji, zato ne čudi, da so ga želeli posnemati. V tem duhu je leta $1920 \mathrm{v}$ okviru Zveze jugoslovanskih učiteljskih društev nastal Pevski zbor tržaškega učiteljskega društva pod vodstvom Srečka Kumarja. Kot pravi Karol Pahor, je idejo o tovrstnem zboru že pred prvo svetovno vojno na Tržaškem razširjal Emil Adamič, ${ }^{15}$ Ivan Grbec pa poudari, da se je porodila v času, ko so moravski učitelji nastopali "po naših krajih $«{ }^{16}$ kar je bilo prvič leta 1907.

Adamiča in Kumarja štejemo za najvplivnejša moža v procesih izobraževanja slovenskih zborovodij med obema vojnama ter ju poznamo kot zaslužna za nastanek novih, predvsem mladinskih zborov ter umetniško vredne, kompozicijsko raznolike, vendar modernistične literature zanje. Ideje o zborovski literaturi in izvajalski praksi, ki naj presežejo narodnobuditeljske težnje in stremijo $\mathrm{k}$ sodobnim umetniškim stvaritvam, sta negovala oba, kar ju je zbližalo že v njunem tržaškem obdobju pred prvo svetovno vojno. Emil Adamič (1877-1936), od mladih let predan učitelj in zborovodja ter mentor številnim zborom, se je $\mathrm{z}$ aktualnim glasbenim dogajanjem in novostmi seznanjal na zborovskih, glasbenopedagoških in skladateljskih strokovnih srečanjih in kongresih na Dunaju, v Nemčiji, na Češkem, v Bolgariji in drugod. ${ }^{17}$ Čeprav je bil kot skladatelj otroških in mladinskih zborov najbolj predan priredbam ljudskih pesmi, se je posebno od 2o. let posvetil razvoju mladinske literature ter ji vdihnil sodobnejši vsebinski in kompozicijski pečat. ${ }^{18}$ Srečko Kumar (1888-1954), najprej učitelj, nato pa kot pianist diplomant tržaškega konservatorija, je že v dijaških letih vodil zbor koprskega učiteljišča in nato pevce društva Zarja v Rojanu, s katerimi se je dokončno zapisal zborovstvu. Nase je opozoril kot zborovodja sodobnega repertoarja, kar je bila v slovenskem narodnozavednem okolju redkost. Kot pravi sam, ga je za sodobno glasbo še pred vojno navdušil učitelj Josef Michl kot pevovodja zbora Glasbene matice v Gorici, ki je med prvimi izvajal dela takrat mladega Antona Lajovca. ${ }^{19}$ Kumar se je aktualnih glasbenih

14 Josip Michl, »Iz koncertne dvorane«, Ljubljanski zvon 43, 1 (1923): 60-61.

15 Jože Zorn, »Učiteljski pevski zbori v ogledalih učiteljskih listov«, Petdeset let Učiteljskega pevskega zbora (Ljubljana: UPZ Emil Adamič, 1975), 10.

16 Zorn, »Učiteljski pevski zbori v ogledalih učiteljskih listov«, 11.

17 Darja Koter, »Emil Adamič«, Novi Slovenski biografski leksikon, obiskano 22. avgusta 2017, http://www.slovenska-biografija.si/oseba/sbi123724/.

18 Prav tam.

19 Albert Širok, »Srečko Kumar«, Petdeset let Učiteljskega pevskega zbora (Ljubljana: UPZ Emil Adamič, 1975), 29. 
gibanj navzel tudi v Leipzigu, kjer je že pred prvo svetovno vojno študiral klavir, gotovo pa tudi na Češkem, kjer je med vojno in po njej vodil pevske zbore. Leta 1919 se je vrnil v Trst in se predal vsestranskemu glasbenemu delovanju in bil med ustanovitelji učiteljskega pevskega zbora, s katerim je med leti 1922 in 1924 zelo uspešno nastopal na širšem Tržaškem, pa tudi v Gorici, Benetkah in Bologni ter prejemal odlične kritike. V naslednjih dveh letih je zbor zaradi vse hujših fašističnih pritiskov in ovir počasi usihal in sredi leta 1926 prenehal delovati. ${ }^{20}$ Zbor učiteljev širše Primorske, Goriške in Istre (Zbor učiteljske zveze za Primorsko) je nastal in deloval po vzorih moravskih učiteljev. Kumar je ansambel vsestransko glasbeno in pevsko izobraževal ter skrbel za tehten in sodoben repertoar, ki ga je pridobil tako, da se je obrnil na slovenske skladatelje in jih spodbudil $\mathrm{k}$ novim delom. $\mathrm{O}$ svojem delu je izjavil:

"Poskusil sem izluščiti glasbeni 'šund' s programov naših koncertov, propagiral sem modernejšo strujo pri nas, od vseh omalovaževano, animiral sem naše skladatelje, da so se vrgli na delo s še večjo vnemo. ${ }^{21}$

Med drugim je izvedel Antona Lajovca Pomladni spev, ki je postal zborov emblem, ter Emila Adamiča Kregata se baba in devojka. Kumrovi pobudi so se odzvali tudi drugi skladatelji, Ivan Grbec, Vasilij Mirk, Emil Komel, Stanko Premrl, Janko Ravnik in Vinko Vodopivec. ${ }^{22}$ Kumarjev učiteljski zbor je ob povedanem uresničeval tudi druge cilje, kot je glasbeno izpopolnjevanje pevcev za zborovodsko delovanje, kar je pomenilo, da je bil zbor ne le pevsko temveč tudi izobraževalno telo. Ta pomemben cilj je širši javnosti predstavil Karol Pahor:

»Naloga pevskega zbora bi bila: gojiti izmed zborovskih skladb (one) najboljše. [...] Lajovic, Ravnik, Kogoj, Foerster idr., ki so do sedaj dvignili umetno pesem najvišje. [...] ki jim zmore biti kos učitelj, ki je v splošnem glasbeno izobražen. Vsak učitelj je dobil na učiteljišču toliko glasbene izobrazbe in bo gotovo težkoče modernih skladateljev tudi zmogel. Nadalje se bodo tu centralizirale vse one učne moči, ki opravljajo po deželi že delo pevovodij, da si bodo po2017, www.slovenska-biografija.si/oseba/sbi309739/; Zorn, »Učiteljski pevski zbori v ogledalih učiteljskih listov«, 11-24.

21 Širok, »Srečko Kumar«, 27.

22 Zorn, »Učiteljski pevski zbori v ogledalih učiteljskih listov«, 11-12. 
tem potom predavanj pridobili na glasbenem polju širše obzorje in bodo mogli opravljati med ljudstvom svojo nalogo na umetniškoglasbenem polju .... $\aleph^{23}$

Hkrati z razvojem učiteljskega pevskega zbora se je pod idejnim vodstvom Srečka Kumarja na širšem Primorskem razgibalo tudi mladinsko petje, označeno kot novo glasbeno gibanje, ki je rojevalo sodobnejšo zborovsko literaturo. ${ }^{24} \mathrm{~V}$ šestdeset članskem učiteljskem zboru je bila kar polovica pevovodij, ki so na podeželju v šolah in društvih vzgajali pevski naraščaj. ${ }^{25}$ Kumarja lahko označimo za glasbenega vizionarja, saj se je zavedal preživelosti vsebinskih in glasbenih značilnosti skladb, ki so jih otroci običajno prepevali pri razrednem zborovskem petju. Bile so vsebinsko okorne ter daleč od otrokovega miselnega in čustvenega sveta. Po glasbeni plati so se opirale na ljudsko ali tujo umetno pesem, imele otrokom neprilagojen glasovni obseg, melodične, ritmične in druge glasbeno-tehnične nerodnosti in ne nazadnje so bile večinoma umetniško šibke. ${ }^{26}$ Vse to ga ja spodbudilo, da je nagovoril skladatelje in jih prepričal k snovanju sodobnejših in tehtnejših mladinskih skladb, pri katerih bi bilo potrebno upoštevati značilnosti otrokovega psihološkega in glasbenega razvoja ter izbirati primerna in tehtna besedila. Ne nazadnje si je prizadeval, da bi bila nova dela vsaj simbolni odsev tedanjega družbeno-političnega stanja primorskih Slovencev, ki so bíli neusmiljen boj s fašizmom. Da bi bile skladbe tudi vsebinsko in idejno primerne, je celo sam zbiral besedila in jih pošiljal skladateljem. ${ }^{27}$ Njihov odziv je bil več kot zadovoljiv: 49 del enajstih avtorjev je Kumar leta 1924 izdal v zbirki Otroške pesmi (E. Adamič, M. Kogoj, I. Grbec, A. Lajovic, K. Pahor, V. Vodopivec...). Zbirka je bila takoj opažena in označena kot izjemna novost in brez primere $\mathrm{v}$ širšem evropskem prostoru. Časopis Učiteljski tovariš je objavil recenzijsko poročilo, ki pravi:

"Končno je naša mladina v pričujoči zbirki dobila pesmarico, skakoršno se niti veliki narodi zlepa ne morejo ponašati. [...] poznam češke, ruske, nemške, ruske in italijanske, seveda tudi hrvaške in

23 Povzetek zapisa Karola Pahorja v učiteljskem časopisu Tržaški list II, 8 (1921), 16. 4. 1921, III.

24 Rafael Ajlec, "Za uvod", Slavček. Pesmarica mladinskih zborov, ur. A. Šuligoj (Ljubljana: Svet zveze Svobod in prosvetnih društev Slovenije, 1957), XII.

25 Širok, »Srečko Kumar«, 27.

26 Cvetko Budkovič, Razvoj slovenskega mladinskega zborovskega petja na Slovenskem: od začetkov do druge svetovne vojne (Ljubljana: Partizanska knjiga, 1983), 9-26. 
srbske, toda tozadevna literatura je skoraj povsodi tako uboga in neumetniška ....1 ${ }^{28}$

Pisec nato opozori, da so med objavljenimi pesmimi zahtevnejše, za bolj izobražene učitelje zborovodje, pa tudi lažje, a umetniško vredne, »ki bodo kaj kmalu izpodrinile brezsmiselno, dolgočasno prepevanje šablonskih, vse prej kot lepih pesmic. «9 $^{29}$ Besedila skladbic so večinoma dobro prilagojena otroški duši, predvsem pa so umetniško vredna in sledijo glasbenim spodobnostim mladih pevcev. Prevladujejo razpoloženjske, nekaj je predelanih narodnih in nabožnih besedil, posamezne pa so aktualne družbene prispodobe, vendar presenetljivo med njimi ni bilo skladb z izrazito socialno tematiko. Po glasbeni strukturi izstopajo dela Marija Kogoja, ki so tudi najštevilčnejša. ${ }^{30} \mathrm{O}$ Kogojevih delih, od katerih so mladinski zbori nastali prav na pobudo Srečka Kumarja, je le-ta tik pred izidom zbirke povedal:

"Kogoj pa je silen. Njegovo dosedanje ustvarjanje je vulkansko, vino $v$ vretju, ko se čisti. Čustvo je pri njem gigantsko močno, a preobloženo je z bogatim, mestoma prisiljenim in nenavadnim ritmom in z najekstremnejšo harmonijo, ki tonaliteto večkrat popolnoma ubije. Njegovi načrti so drzni kot njegov obraz. Zdi se, da je $v$ Kogoju večno živa želja napisati nekaj formalno popolnoma novega. [...] piše za zbor tako, da omaga pri skladbi celo orkester. Iz najglobljega trpljenja klijejo njegove stvari in vse njegove skladbe bi se dale strniti pod skupen naslov: himna trpljenja. Čeprav so njegove nove skladbe tako silne po čustvu, da prenesejo vso njegovo nečisto materijo, niso še cilj, so šele pot, so šele dragoceno izpričevalo njegovega razvoja, orglje, $k i$ se počasi kristalizira $v$ diamant. " $^{31}$

Kogojeva kompozicijska načela so temeljila na popolni osvoboditvi od preteklosti, romantike in impresionizma, in bila proti vsakršnim efektom, pri čemer se je zavzemal, da treba

»izvršiti popolno očiščenje in ustvariti objektivne vrednote, $k i$ bi bile vedno zmožne delovati na notranjost človeka [...]; izgnati iz N. N., »Otroške pesmi. Uredil Srečko Kumar«, Učiteljski tovariš, št. 21, 22. 5. 1924, 2. Prav tam.

30 Prim. Otroške pesmi, ur. S. Kumar (Trst: Zveza slovanskih učiteljskih društev v Italiji, 1924).

31 Širok, »Srečko Kumar«, 30. 
muzike vsako sentimentalnost in dobiti zdrav, močan izraz zdravemu, močnemu čustvu. $\aleph^{32}$

Svojih hotenj sicer ni povsem uresničil in ni zašel na področje atonalnosti. Svojemu prepričanju je sledil tudi v eno in dvoglasnih otroških pesmih, nastalih v enem zamahu leta 1922 ali 1923 . Zanje je skrbno zbiral besedila, se izogibal melodičnim stereotipom, nihal med modalnim in tonalnim, imitiral in ustvaril izviren ekspresionistični izraz, ki temelji na povednosti besedil, svojstvenih intervalnih razmerjih, subtilnih variacijah ter ne nazadnje na svobodnih ritmičnih in metričnih postopih..$^{33} \mathrm{Kmalu}$ po izidu Kumrove zbirke so njene skladbe zaživele v osnovnih šolah, kjer so petje vodili pevci Kumrovega učiteljskega zbora, ki so njegovo znanje ter ideje zborovskega petja prenašali na mlajše rodove. ${ }^{34}$ Med njimi je posebej izstopal Avgust Šuligoj, ki se je izkazal za odličnega mentorja otroškega oziroma mladinskega petja na različnih primorskih osnovnih šolah in nekaj kasneje postal spiritus agens mladinskega petja $\mathrm{v}$ osrednji Sloveniji.

Srečko Kumar se je leta 1924 kot gostujoči zborovodja Glasbene matice predstavil v Ljubljani, ${ }^{35}$ ko pa je bil dve leti kasneje zaradi fašizma primoran razpustiti svoj primorski učiteljski zbor, se je zatekel v Ljubljano ter se vključil v vseslovensko zborovsko gibanje. Njegovi akterji, med njimi Anton Lajovic, so si že od konca vojne prizadevali, da bi po moravskih vzorih ustanovili zbor vseslovenskega učiteljstva. Ideja je zorela v posameznih krajih, $v$ manjših sestavih učiteljev, do združenega pevskega zbora pa je prvič prišlo leta 1924, ko je Zveza slovenskih zborov v Ljubljani priredila koncert združenih zborov pod vodstvom Zorka Prelovca. ${ }^{36}$ Do končne uresničitve vseslovenskega pevskega zbora učiteljev je prišlo sredi leta 1925 na pobudo Društva učiteljev glasbe, katerega predsednik je bil Marko Bajuk, tajnik pa Adolf Gröbming. V pozivu k ustanovitvi ansambla je društvo zapisalo:

»Moderne zborovske skladbe zahtevajo glasbeno naobraženih pevcev, [...] najboljše pevce moremo iskati med učiteljstvom, [...] dokaz temu je zbor učiteljev v Južni Benečiji, ki se je v nekaj letih popolnoma uveljavil ne le pri rojakih, temveč tudi pri Italijanih sa-

32 Marij Kogoj, »Smer glasbe v zadnjem desetletju«, Ljubljanski zvon 43, 6 (1923): 324.

33 O teksturi Kogojevih otroških pesmih glej tudi: Borut Loparnik, »Prvine melodične dikcije Kogojevih otroških pesmih", Muzikološki zbornik 5 (1969): 54-70.

34 Ajlec, »Za uvod«, XIII.

35 Prim. Zorn, »Učiteljski pevski zbor med obema vojnama«, 35.

36 Prav tam. 
mih. [...] Kaj premore dobro organiziran zbor, priča tudi zbor moravskih učiteljev. Delovanje tega zbora je bilo tako uspešno, da je produktivno vplivalo na produktivno češko glasbeno umetnost. Odprl je skladateljem nove perspektive in nastale so mogočne širokopotezne skladbe ... Pri nas čaka nešteto krasnih skladb moderne koncepcije za izvajanje. Pretežke so za naše zbore, ne bi pa bile za zbor glasbeno naobraženih pevcev. Zato je dolžnost našega učiteljstva, da tu zastavi svoje moči in pomaga moderni slovenski pesmi na noge. «7

K uresničevanju ideje o pospeševanju nastajanja novih, sodobnejših skladb in višjega nivoja poustvarjalnosti sta dejavno pripomogla soustanovitelja zbora Emil Adamič in Srečko Kumar, ki je postal tudi dirigent s smelimi in večplastnimi cilji. Privabljali so učitelje širšega slovenskega ozemlja, tudi primorske Slovence, nekdanje Kumarjeve pevce. Od pevcev je bila pričakovana višja izobrazbena raven petja in usposabljanje za vodenje odraslih in šolskih zborov. $\mathrm{V}$ ta namen so organizirali večdnevne pevske tečaje in skupne vaje, kjer so se pevci urili v vokalni tehniki, glasbeni teoriji, dirigiranju ... Posledično je bilo pričakovati rast novih zborov ter tehnični in umetniški dvig otroškega in mladinskega petja. Kumar je tudi ta učiteljski zbor pojmoval kot "poligon« izobraževanja zborovodij, kar je pred leti uresničil na Tržaškem. Ker si je zadal, da bo ansambel poustvarjalno telo najnovejše zborovske glasbe, je skladatelje slovenskega in širšega jugoslovanskega prostora spodbujal k novim, kompozicijsko aktualnejšim skladbam, ki naj bi jih predstavljali tudi v mednarodnih okvirjih. Zaradi drugačnih družbeno-političnih razmer pa je nekoliko v ozadje stopila narodnobuditeljska nota, ki jo je nadomestila usmeritev k socialni problematiki in novim družbeno-političnim razmeram časa. Zastavljene cilje je ansambel pod Kumarjevim vodstvom ter idejni in strokovni podpori Adamiča uspešno uresničeval. V nekaj letih je zaživel kot umetniško telo $\mathrm{z}$ velikimi ambicija$\mathrm{mi}$ in izrazito sodobnim repertoarjem. Izvedel je številne novitete slovenskih in jugoslovanskih skladateljev aktualne dobe, $s$ katerimi se je predstavljal $v$ domačem in mednarodnem prostoru, iz njegovih vrst pa je izšla tudi vrsta dobrih zborovodij, ki so delovali v kulturnih društvih in šolah. ${ }^{38} \mathrm{Zbor}$

37 Marko Bajuk in Adolf Gröbming, »Ustanovimo učiteljski pevski zbor«, Učiteljski tovariš 63, 30 (1923), 23. 7. 1923, 2 .

38 Zorn, »Učiteljski pevski zbor med obema vojnama«, 38-54. Za sintezo razvoja zborovstva med obema vojnama glej: Darja Koter, Slovenska glasba 1918-1991 (Ljubljana: Študentska založba, 2012), 83-85. 
učiteljstva je užival vsestransko navdušenje in dobival pohvalne kritike. ${ }^{39}$ Njegove ideje, stremljenje k odličnosti ter sodobnemu repertoarju, so široko odmevale in posebno spodbudile razvoj mladinskih zborov po osnovnih šolah, kjer se je dotlej pretežno gojilo enoglasno razredno petje preprostih, vsebinsko in glasbeno-tehnično ne dovolj primernih pesmi. Ideja o potrebi po razvoju mladinskega petja $\mathrm{v}$ pevskem oziroma glasovnem in repertoarnem pogledu, je kmalu prinesla novo kvaliteto: učitelji zborovodje, Kumarjevi pevci, so spoznavali, da v okviru razrednega petja ni mogoče doseči zares ubranega petja in umetniške poustvarjalnosti, zato so drug za drugim ustanavljali šolske mladinske pevske zbore izbranih pevcev, jih pevsko izobraževali in posegali po zahtevnejših oziroma tehtnejših in sodobnejših skladbah.

Med prvimi, ki so sledili tej ideji, je bil Avgust Šuligoj, ki je od leta 1927 poučeval $\mathrm{v}$ osnovni in meščanski šoli Trbovlje-Vode in tam vodil tudi mladinski pevski zbor, kasneje preimenovan v Trboveljski slavček. Kot učitelj je bil osupel nad težkimi socialnimi razmerami tamkajšnjih otrok. Prišel je namreč v času velike gospodarske krize, ki je še posebno prizadela rudarje in njihove družine. Ob vsakodnevnem opazovanju težkih življenjskih pogojev bolehnih in slabotnih otrok pa je pri učencih zaznal izjemno pevsko nadarjenost, zato je začel iskati oblike, kako mladim olajšati mladost in razvijati njihove naravne danosti. Možnost omilitve duševnih stisk je videl v vsestransko ambicioznem pevskem zboru, ki bi pevcem omogočil lepše življenje. Ko je spoznaval socialne razmere, se je zavedal, da v novih časih, prežetih s številnimi drugimi grenkobami, narodnostna ideja ni več v ospredju. Zbor rudarskih otrok je zasnoval kot ansambel takrat revolucionarnih socialnih idej..$^{40} \mathrm{~V}$ ospredje je postavljal iskrene medsebojne odnose, »da predstavlja zborovska družina nekaljivo harmonijo in nedeljivo celoto $z$ enim hotenjem in eno voljo « in šele nato glasbeno izobrazbo in ambicijo dirigenta. ${ }^{41}$ Prav poglobljen in pristen odnos s pevci mu je prinesel sugestivno moč, s katero je z zborom dosegal dotlej na Slovenskem nezmožne umetniške presežke. Pot do slavnega Trboveljskega slavčka pa ni bila lahka. Šuligoj je v prvem letu z zborom sicer nastopil v trboveljskem Delavskem domu, vendar se je kmalu zavedal, da ima za uresničitev svojih idej pomanjkljivo izobrazbo in premalo izkušenj z metodami zborovskega dela. Šolsko delo

39 Jože Župančič, »Učiteljski pevski zbor v polnem razmahu«, Učiteljski tovariš 71, št. 41 (1931), 26. 11. 1931, 3.

40 O Šuligojevem življenju in ustvarjanju glej: Ajlec, »Za uvod«, XV.

41 Avgust Šuligoj, "Moja pot«, Slavček. Pesmarica mladinskih zborov, ur. A. Šuligoj (Ljubljana: Svet Zveze Svobod in prosvetnih društev Slovenije, 1957), XVIII. 
je za nekaj časa prekinil, se samoizobraževal ter študijsko potoval v Prago in na Dunaj, kjer se je seznanil z načini dela dveh slavnih zborov: z Bakulovo pevsko družino v Pragi ter z zborom Dunajskih dečkov. Nato se je še izčrpneje posvetil proučevanju življenjskih prilik trboveljskih rudarjev in njihovih otrok ter o tem objavil nekaj alarmantnih člankov. Bil je tako prodoren, da so mu oblasti nadaljnje objave prepovedale. ${ }^{42}$ Vse to pa mu ni preprečilo uresničiti ideje o stalnem mladinskem pevskem zboru, ki bi bil s poglobljenim vokalnim izobraževanjem in umetniškim poustvarjanjem sposoben izvajati najnovejša in zahtevna dela slovanskih avtorjev, tudi izven trboveljske kotline, $\mathrm{v}$ mednarodnem prostoru. Leta 1930 je $\mathrm{v}$ ta namen na deški in dekliški osnovni šoli Trbovlje-Vode zbral okrog sto pevcev in že čez nekaj mesecev z njimi izvedel samostojni koncert. Njegova pot je šla strmo navzgor, nastopi so se vrstili vse bliže Ljubljani, nato v drugih slovenskih krajih in kmalu tudi na Češkoslovaškem in na Dunaju. Kritiki so zbor in dirigenta slavili in kovali $\mathrm{v}$ zvezde. ${ }^{43} \mathrm{Ob}$ študiju izbrane pevske literature se je Šuligoj zavedal potreb po skladbah s socialno noto, ki jih skladatelji dotlej niso namenjali otrokom, zato se je povezal z nekaterimi pesniki in skladatelji. Prvo takšno pesem je zboru posvetil Emil Adamič na besedilo Vlada Klemenčiča in nosi pomenljiv naslov: Pesem rudarskih otrok (nastala avgusta 1931). Ta skladba je kmalu postala zborova himna, ki so jo na zahtevo občinstva redno prepevali na začetku in ob zaključku koncertov. ${ }^{44}$ Nič manj grenkobna ni bila Pesem beračev (bes. Oskar Hudales, izvirno Pesem ubožcev), ki jo je prav tako uglasbil Emil Adamič (1933), vendar je zaradi vsebine in sugestivne uglasbitve zbor ni smel izvajati (prva izvedba leta 1940). ${ }^{45}$ Še posebno pretresljiva je bila tožba za umrlim očetom Čaće moj Ivana Matetića-Ronjgova (nastala po tragični rudarski nesreči v Trbovljah leta 1932). Matečić je med prvimi pisal priredbe istrskih ljudskih pesmi in kljub zahtevnosti in posebnosti istrske lestvice jih je Šuligojev zbor uspešno izvajal, kar je skladatelja spodbudilo k nastanku tožeče pesmi Čaće moj, posvečene Slavčkom. Le-ti so jo večkrat prepevali z izjemnim uspehom, tudi na velikih mednarodnih shodih, kot je bil leta 1936 v Pragi ob prvem mednarodnem kongresu za sodobno glasbeno vzgojo, kjer so bili Trboveljski slavčki

\footnotetext{
42 Jože Skrinar, Trboveljski slavček od srca k srcu (Trbovlje: Mešani zbor Slavček, 1971), 10.

Nekaj udarnejših kritik je objavil Jože Skrinar v delu Trboveljski slavček od srca k srcu, 39-42.

44 Prav tam, $17-18$.

45 Prav tam, 18.
} 
posebni gostje. ${ }^{46}$ Šuligoj je imel pretanjen občutek za glasbeno literaturo in je znal zbrati najtehtnejše in kompozicijsko primerne skladbe, $s$ katerimi se je zbor izkazal tako po tehnični kot muzikalni plati, ne glede na to, ali so izvajali priredbe ljudskih ali umetne pesmi. Najprej se je naslonil na Emila Adamiča in Slavka Osterca, ki sta se njegovim sugestijam odzvala in pisala na ljudska in sodobna pesniška besedila ter postala velika prijatelja in pokrovitelja zbora. Številne pesmi sta zboru tudi posvetila. Osterc med drugimi tudi svoj znameniti Kvartet na satirično basensko besedilo ruskega pisatelja Ivana Krilova (1769-1844), s katerim je simbolično ošvrknil tedanjo jugoslovansko vlado, kot sokrivo za šibko socialno stanje rudarskih otrok. Skladbo je Osterc opredelil kot atonalno. ${ }^{47}$ Delo sicer kaže atonalne težnje, vendar vsebuje tudi tonalne centre in še danes velja za eno najzahtevnejših skladb mladinske literature medvojnega časa.

Do leta 1934, ob 100 koncertu, je imel Trboveljski slavček kot promotor slovenske in slovanske sodobne mladinske zborovske literature zaokroženo tehten repertoar, ki je večinoma obsegal modernistična dela Emila Adamiča, Marija Kogoja, Slavka Osterca, Zorka Prelovca, Karola Pahorja, Vasilija Mirka, Matije Bravničarja in drugih slovenskih avtorjev, med kompozicijami hrvaških in srbskih skladateljev pa so bile skladbe Zlatka Grgoševića, Marka Tajčevića, Ivana Matetića-Ronjgova, Miloja Milojevića, Petra Krstića, Mladena Pozajića, Stevana Mokranjca in ne nazadnje Borisa Papandopula. Vsi omenjeni so sodili med najvidnejše slovenske oziroma jugoslovanske skladatelje, njihova dela za Trboveljski slavček pa izstopajo po aktualnih besedilih in takrat sodobnih kompozicijskih prijemih, ki so zahtevali odlično pevsko tehniko, pretanjen posluh in zavzet odnos do povednosti besedil. Šuligoj je namreč kmalu izčrpal Kumarjevo zbirko Otroških pesmi iz leta 1924, predvsem pa je potreboval skladbe $\mathrm{z}$ drugačno vsebino, ideološko naravnane na družbene razmere, v katerih je deloval. Kot se je izkazalo, so prav pesmi s socialno noto poslušalce najbolj prepričale in ganile. Pregled priredb ljudskih pesmi kaže na to, da so bile izvirne predloge zgolj zvočno ogrodje za modernistične poteze in povsem nov pristop do predelav ljudskih motivov. V splošnem prevladuje iskanje novih sozvočij, menjavanje slogovnih značilnosti, uveljavljanje novih kompozicijskih tehnik, intervalno in harmonsko slikovita in pevsko zahtevna dela, ki segajo do roba ekspresivnosti in celo do atonalnosti. Ob tem se zdi povsem naravno, da so skladatelji premišljeno izbirali besedila, glasbeni stavek pa ostrili toliko, da je bil za otroško dojemanje glasbe muzikalno in tehnično sprejemljiv, ven-

46 Prav tam, 21.

47 Prav tam. 
dar so kmalu spoznali, da so Slavčki sposobni izvajati glasbeno-tehnično in izrazno najzahtevnejša dela. Slavčkov repertoar je po izvirnosti in aktualnosti presegel vsa društva, odrasle in mladinske zbore. $\mathrm{Z}$ njim se je rodilo pravo glasbeno gibanje, ki je spodbujalo nove in nove mladinske zbore, nastajanje številnih skladb in notnih zbirk, med pomembne vzgibe pa sodi tudi revija Grlica, ki sta jo med leti 1933 in 1935 v Zagrebu izdajala Ivan Grbec in Srečko Kumar. Njuna Grlica je postala osrednja revija za izdajanje sodobno naravnanih jugoslovanskih skladb za mladinske zbore, prinašala pa je tudi aktualne članke o vlogi in razvoju zborovskega petja in glasbenega pouka v osnovnih šolah.

Trboveljski slavčki so bili slavni doma in na tujem, kjer so jih primerjali z obema že omenjenima zboroma, praškim in dunajskim, nekateri pa so ga postavljali celo na piedestal pred vsemi. Številni koncerti so bili dobrodelni, v korist rudarskih otrok, pomoči najbolj potrebnim, pa tudi za gostovanja in letovanja na morju, kar je bila pevcem najlepša nagrada. Slavčkovo poslanstvo je tudi $z$ današnjimi očmi neizmerno: spodbujal je nove mladinske zbore, ki so zlagoma nadgradili nekoč prevladujoče šablonsko razredno petje, razvijali vokalno tehniko, izobraževali v glasbeni teoriji ter kot vrhunec stremeli k višji umetniški ravni poustvarjanja. Gibanje mladinskih zborov smemo šteti za pomemben dejavnik repertoarne tranzicije $\mathrm{k} »$ novemu«, Avgusta Šuligoja pa za najpomembnejšega akterja pri nastajanju in promoviranju mlade slovanske glasbene literature za mladinske zbore. Za njegov zbor je nastalo okrog 800 skladb, izvedenih na koncertih in radijskih postajah, kar je poslanstvo mladih pevcev še stopnjevalo. Za sistematični razvoj mladinskega poustvarjanja je bila zaslužna vrsta napredno mislečih učiteljev zborovodij, kot so Emil Adamič, Srečko Kumar, Avgust Šuligoj, Ivan Grbec, Ciril Pregelj, Makso Pirnik, Vasilij Mirk, Jurče Vreže in drugi, ki so v različnih slovenskih krajih delovali kot zborovodje, skladatelji in organizatorji pevskih koncertov. Posebej prelomno je bilo leto 1934, ko je bil v Ljubljani izveden prvi mladinski pevski festival. S svojo množično zasnovo je k sodelovanju privabil skoraj vse najvidnejše zborovodje in njihove sestave. Odmevna prireditev ni ostala brez dolgoročnih vplivov, med katerimi je potrebno izpostaviti rast novih mladinskih zborov, razširjanje umetniško in sodobno naravnanega programa ter poglobljenega pevskega izobraževanja. Čeprav je druga svetovna vojna razmah mladinskega zborovstva nasilno prekinila, je tradicija preživela in se nadaljevala po letu 1945. Novi časi so prinesli drugačne poglede na poslanstvo zborovskega petja, nove idejne poglede ter ideološko obarvane repertoarje, med kompozi- 
cijskimi načeli pa ni bilo prostora za moderniste predvojnega časa. Vse to je vplivalo na to, da je Trboveljski slavček, čeprav po vojni obujen, kmalu za$\mathrm{mrl}$ in ni imel pravih naslednikov. Zborovodje mladinskih zborov so hote ali nehote sledili idejnim zapovedim socializma, kjer pa ni bilo prostora za najnovejše kompozicijske tehnike zahodnega sveta.

\section{Bibliografija}

Bajuk, Marko in Gröbming, Adolf. »Ustanovimo učiteljski pevski zbor«. Učiteljski tovariš 63, št. 30 (1923), 23. 7. 1923, 2.

Budkovič, Cvetko. Razvoj slovenskega mladinskega zborovskega petja na Slovenskem: od začetkov do druge svetovne vojne. Ljubljana: Partizanska knjiga, 1983.

Dolenc, Ervin. »Avantgarda v umetnosti - konstruktivizem«. Slovenska kronika XX. stoletja, ur. M. Drnovšek in D. Bajt. Ljubljana: Nova revija, 1995, 307.

Dom in svet, leta 1926-1931.

Kogoj, Marij. »Smer glasbe v zadnjem desetletju«. Ljubljanski zvon 43, 6 (1923): 324.

Komelj, Milček. »Umetnost med obema vojnama«. Umetnost na Slovenskem Od prazgodovine do danes, Stane Bernik et al. Ljubljana: Mladinska knjiga, 1998, 263-70.

Koter, Darja. »Glasbena revija Nova muzika - Adamič kot urednik«. Adamičev zbornik. Ljubljana: Akademija za glasbo, 2004, 63-75.

Koter, Darja. »Matija (Frane) Bravničar - prispevek k biografiji«. Matija Bravničar: (1897-1977): tematska publikacija Glasbeno-pedagoškega zbornika Akademije za glasbo v Ljubljani, zv. 9, ur. D. Koter. Ljubljana: Akademija za glasbo, 2008, 7-24.

Koter, Darja. Slovenska glasba 1918-1991. Ljubljana: Študentska založba, 2012.

Koter, Darja. »Emil Adamič«. Novi Slovenski biografski leksikon. Obiskano 22. avgusta 2017. http://www.slovenska-biografija.si/oseba/sbi123724/.

Kumar, Srečko, ur.. Otroške pesmi. Trst: Zveza slovanskih učiteljskih društev v Italiji, 1924.

Loparnik, Borut. »Prvine melodične dikcije Kogojevih otroških pesmih«. Muzikološki zbornik 5 (1969): 54-70.

Michl, Josip. »Iz koncertne dvorane«. Ljubljanski zvon 43, 1 (1923): 60-61.

Osterc, Slavko. »Glavne struje sodobne glasbe in njih eksistenčna upravičenost«. Nova muzika 1, 1 (1928): 1-2. 
Premrl, Stanko. »Koncerti moravskih učiteljev«. Dom in svet 21, 3 (1908): 140.

Ajlec, Rafael. »Za uvod«. Slavček. Pesmarica mladinskih zborov, ur. A. Šuligoj. Ljubljana: Svet zveze Svobod in prosvetnih društev Slovenije, 1957, XII-XXIV.

Skrinar, Jože. Trboveljski slavček od srca k srcu. Trbovlje: Mešani zbor Slavček, 1971.

Širok, Albert. »Srečko Kumar«. Petdeset let Učiteljskega pevskega zbora. Ljubljana: UPZ Emil Adamič, 1975, 25-29.

Šuligoj, Avgust. Slavček. Pesmarica mladinskih zborov, ur. A. Šuligoj. Ljubljana: Svet Zveze Svobod in prosvetnih društev Slovenije, 1957.

Valentinčič, Emil. »Srečko Kumar«. Primorski biografski leksikon. Obiskano 6. marca 2017. www.slovenska-biografija.si/oseba/sbizo9739/.

Vurnik, Stanko. »Umetnost in družba ter umetnostna politika«. Ljubljanski zvon 46, 4 (1926): 244.

Vurnik, Stanko. Uvod v glasbo. I. Sistematični del. Ljubljana: Nova založba, 1929.

Vurnik, Stanko. »K problemu sodobne kulturnosti«. Dom in svet 43, 5/6 (1930): 1.

Vurnik, Stanko. »H krizi naše Opere«. Dom in svet 43, 1-2 (1930): 58-59.

Vurnik, Stanko. »Glasbeno življenje v Ljubljani 1. 1930«. Dom in svet 44, 1-2 (1931): 95 .

Zorn, Jože. »Učiteljski pevski zbori v ogledalih učiteljskih listov«. Petdeset let Učiteljskega pevskega zbora. Ljubljana: UPZ Emil Adamič, 1975, 10-24.

Župančič, Jože. »Učiteljski pevski zbor v polnem razmahu«. Učiteljski tovariš 71,41 (1931), 26.11.1931, 3. ${ }^{48}$

48 Poglavje je nastalo kot del projekta J6-718o, ki ga je sofinancirala Agencija za raziskovalno dejavnost Republike Slovenije.

This chapter is part of the project J6-7180 funded by Slovenian research agency ARRS. 